\title{
JUURNAL.RU
}

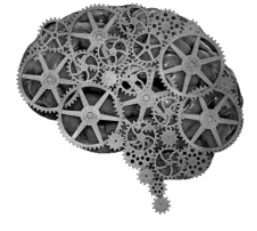

COMPANY GROUP "INTELLEKT"

\author{
Власов М.В., Федоров С.К. \\ МГТУ им. Н. Э. Баумана \\ Москва, Россия
}

doi: 10.18411/lj2016-6-2-03

\section{Анализ износа эвольвентных зубчатых передач и методы повышения износостойкости}

В конструкциях машин и механизмов различного назначения большое распространение получили эвольвентные зубчатые профили. Анализ износа таких деталей показал, что значительное большинство выходит из строя, имея низкие эксплуатационные свойства поверхностного слоя зубьев. Именно поверхностный слой во многом определяет износостойкость, сопротивление материала усталостному разрушению, контактную выносливость, коррозионную стойкость и другие важные эксплуатационные свойства.

Основными видами разрушений зубчатых колес являются излом зубьев, усталостное выкрашивание, изнашивание и заедание зубьев (рис. 1).

Различают два вида излома зубьев. Излом от больших перегрузок, а иногда от перекоса валов и неравномерной нагрузки по ширине зубчатого венца и усталостный излом, происходящий от длительного действия переменных напряжений изгиба.

Усталостное выкрашивание рабочих поверхностей зубьев характерно для большинства закрытых быстроходных передач, работающих при смазке. Оно является следствием длительного действия переменных контактных напряжений, вызывающих усталость материала зубьев.

Изнашивание зубьев - основной вид разрушения зубьев открытых передач, а также закрытых, но недостаточно защищённых от загрязнения абразивными 
частицами. По мере изнашивания первоначальный эвольвентный профиль зубьев искажается, увеличиваются зазоры в зацеплении, возникают динамические нагрузки и повышенный шум. Основные меры предупреждения износа - повышение твёрдости зубьев, защита от загрязнения и др.

Заедание зубьев происходит преимущественно в высокоскоростных быстроходных передачах. В месте контакта зубьев развиваются высокие давления и температура, масляная плёнка разрывается и появляется металлический контакт. Происходит как бы сваривание частиц металла с последующим отрывом их от менее прочной поверхности. Образовавшиеся наросты на зубьях задирают поверхности других зубьев, оставляя на них широкие и глубокие борозды в направлении скольжения [3].

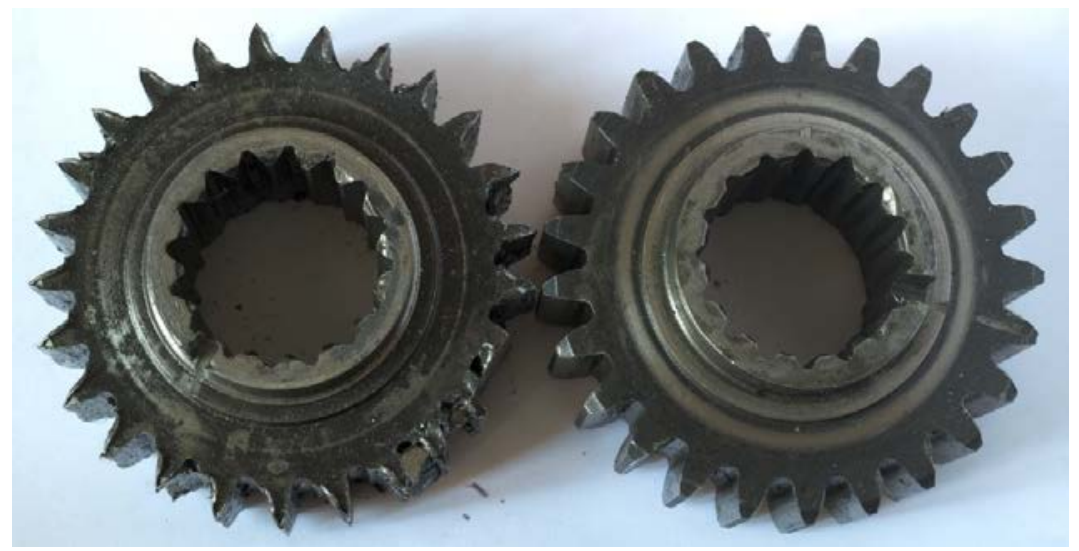

Рис. 1. Изношенные эвольвентные зубчатые колеса

На предприятиях детали после механической обработки по нарезанию зубчатых профилей подвергают термическим способам закалки. Это, прежде всего, объемная термическая обработка, закалка токами высокой частоты, химико-термическая обработка. Широкая номенклатура деталей с эвольвентными зубчатыми передачами имеет низкие показатели качества по твердости, прочности, износостойкости, усталостной долговечности, циклической прочности. Кроме того, многие процессы из термической обработки являются вредными и экологически небезопасными для человеческого организма. При термической обработке присутствуют такие дефекты как неравномерная твердость по сечению, возможно появление 
термических микротрещин и развитие микротрещин от механической обработки, окисление и обезуглероживание поверхностного слоя, сложность последующей финишной обработки шлифованием и хонингованием [2].

Для деталей с зубчатым профилем применение объемной термической обработки обеспечивает только общую прочность детали, в то время как по условиям эксплуатации требуется дополнительная закалка зубьев. Закалка ТВЧ, повышая твердость зубьев, приводит к их короблению. При малых модулях зубчатого соединения опасно прокаливание зуба насквозь, что делает зуб хрупким. Последующая рихтовка является трудоемкой и малоэффективной мерой повышения качества деталей. В процессе химико-термической обработки имеют ограничения по размеру и массе зубчатых колес. Процессы ХТОприменяются в условиях крупносерийного и массового производства.

Основная идея работы заключается в том, чтобы целенаправленно формировать показатели качества эвольвентных зубчатых профилей деталей из стали и чугуна с учетом условий эксплуатаций и схемы нагружения зубчатых соединений.

Для осуществления задуманного предлагается использовать эффект электроконтактной закалки и одновременного поверхностного пластического деформирования контактной зоны эвольвентного зубчатого профиля методом электромеханической обработки (ЭМО) [1, 4, 5].

Электромеханическая поверхностная закалка является способом контактной обработки поверхностей высококонцентрированным источником электрической энергии, объединяющим силовое и термическое воздействие инструмента на поверхность заготовки. Высокая скорость нагрева, аналогичная лазерной обработке позволяет получать твердость выше, чем при объемной закалке, закалке ТВЧ и позволяет исключить дефекты, характерные традиционным методам термической обработки.

Конкурентной особенностью данной технологии является возможность гибкого управления параметрами скоростного контактного электронагрева и 
поверхностного слоя с целью формирования уникальных быстрозакалённых структур, изменения микрогеометрии и текстуры волокон металла поверхности, уменьшения размера зерна, уплотнению пористых слоёв, повышения адгезии и когезиинапыленных покрытий.

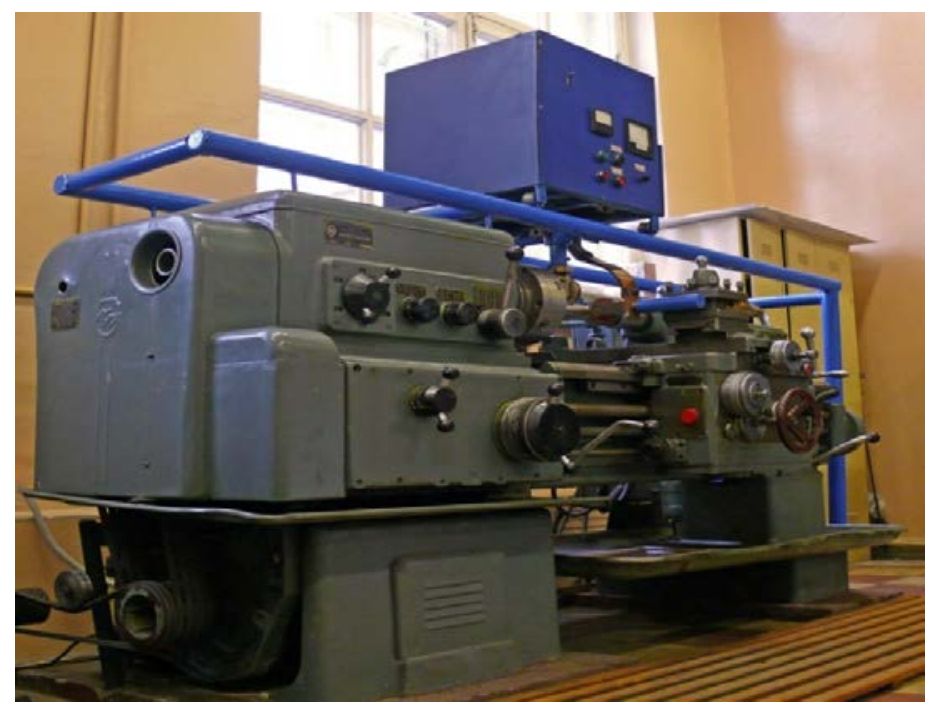

Рис. 2. Фрагмент оборудования ЭМО на токарно-винторезном станке

Инновационное оборудование (рис. 2) и технологии электромеханической обработки формируют уникальные свойства поверхностного слоя деталей, являются экологически чистыми и конкурентоспособными, позволяют получать эксплуатационные свойства поверхностей, недоступные традиционно применяемым методам механической, термической или химико-термической обработок. 


\section{Литература:}

1. Аскинази, Б. М. Упрочнение и восстановление деталей машин электромеханической обработкой [Текст] /Б.М. Аскинази. 3-е изд. перераб. и дополн. - М.: - Машиностроение - 1989. - 197с.

2. Елагина О. Ю. Технологические методы повышения износостойкости деталей машин [Текст] / О. Ю. Елагина. - М.: - Университетская книга 2009 г. 488 c.

3. Машиностроение. Энциклопедия. Детали машин. Конструкционная прочность, трение, износ, смазка. T.IV - 1/Под ред. Д. Н. Решетова. - М.: Машиностроение, 1995.

4. Федоров, С. К. Электромеханическая обработка. / С.К. Федоров, Л.В. Федорова // РИТМ. 2012. №2(70).c. $14-16$.

5. Федоров, С. К.Закалка, отделочно-упрочняющая обработка и восстановление деталей электромеханическим способом. / С.К. Федоров, Л.В. Федорова - М.: 2010. - 60 с. 